\title{
'n Struktuuranalise van Swart sakeondernemings in die Republiek van Suid-Afrika*
}

\author{
J. Kroon \\ Departement Bedryfsekonomie, Potchefstroomse Universiteit vir Christelike Hoër Onderwys, Potchefstroom
}

\begin{abstract}
A structure-analysis of Black business enterprise in the Republic of South Africa. The present situation in South Africa is such that a sophisticated and developed economy and a totally unsophisticated and undeveloped economy exist side by side. In this context the role of entrepreneurs or employers is mainly fulfilled by Whites and the role of employees by Blacks. Reasons for this are, among others, the political historical development in South Africa and the fact that the independent entrepreneur was not part of the Black man's traditional structure. In this context the position of the Black entrepreneur in the Republic of South Africa (excluding independent and national states) is referred to. In particular, attention is given to the development of Black business enterprise in Black residential areas, the physical structure of Black residential areas, the structure of formal Black business enterprise, the informal sector as an important part of the small business sector in Black residential areas, purchasing behaviour of Black consumers, existing purchasing facilities in Black residential areas and the need for certain other purchasing facilities in Black residential areas.

S. Afr. J. Bus. Mgmt. 1984, 15: $182-188$
\end{abstract}

Die huidige situasie in Suid-Afrika is sodanig dat 'n gesofistikeerde en ontwikkelde ekonomie en 'n totaal ongesofistikeerde en onontwikkelde ekonomie langs mekaar bestaan. In hierdie konteks tree Blankes hoofsaaklik as entrepreneurs of werkgewers op. Daarteenoor vervu! Swartes hoofsaaklik die rol van werknemers as gevolg van onder meer die polities-historiese ontwikkeling in Suid-Afrika en die feit dat die onafhanklike entrepreneur nie deel van die Swartman se tradisionele struktuur was nie. In hierdie konteks word hier kortliks na die posisie van die Swart entrepreneur in die Republiek van Suid-Afrika (onafhanklike en nasionale state uitgesluit) venwys. In besonder word die ontwikkeling van Swart sakeondernemings in Swart woongebiede, die fisiese struktuur van Swart woongebiede, die struktuur van die formele Swart sakeondernemings, die informele sakesektor as 'n belangrike onderdeel van die kleinsakesektor in Swart woongebiede, die koopgedrag van Swart verbruikers, inkoopgeriewe en die behoefte aan sekere inkoopgeriewe in Swart woongebiede kortliks bespreek.

S.Afr. Tydskr. Bedryfsl. 1984, 15: $182-188$

-Hierdie artikel is 'n bondige uittreksel van sommige aspekte van die skrywer se D.Com.-studie.

\section{J. Kroon}

Departement Bedryfsekonomie, Potchefstroomse Universiteit vir

C.H.O., Potchefstroom, 2520, Republiek van Suid-Afrika.

\section{Die ontwikkeling van Swart sakeondememings in Swart woongebiede:}

Sosio-ekonomiese en politieke kragte is in gedurige wisselwerking met mekaar. Gevolglik trek die arbeidsaanvraag van nywerhede in die stedelike gebiede die aanbod van arbeid uit die tuislandse aan. Dit lei tot verstedeliking wat grootliks deur politieke besluitneming bepaal word (Smit \& Booysen, 1981). Die resultaat van hierdie sosio-ekonomiese en politieke wisselwerking het onder meer gelei tot die totstandkoming van Swart woongebiede.

Reeds aan die begin van die eeu was ' $n$ eie besigheid vir Swartes ' $n$ middel tot die bevrediging van hoër aspirasies toe slegs enkele Swart sakeondernemings in Suid-Afrika bedryf is. Met die ontstaan van Swart woongebiede op oop grond naby Blanke stede en dorpe het die aantal Swart sakeondernemings in Swart woongebiede geleidelik vermeerder. Handel in Swart woongebiede was tot die Swart inwoners beperk.

In 1930 was handel onder Swartes aan die Witwatersrand so populêr dat die aantal handelaars beperk moes word. Gedurende die veertigerjare word Swart verstedeliking deur die arbeidsaanvraag van nywerhede gestimuleer en Swart sakebedrywighede in stedelike Swart woongebiede bly onderontwikkeld. In die vyftigerjare het die aantal en soorte Swart sakeondernemings in Swart woongebiede geleidelik vermeerder. Gedurende die sestiger- en vroee sewentigerjare van die ontwikkelingsgeskiedenis val die klem op tuislandontwikkeling en die gevolglike tydelike status van die Swart bevolking en Swart handelaars. Dit lei tot 'n gebrekkige voorsiening van handelsgeriewe in Swart woongebiede in só 'n mate dat ongeveer $58 \%$ van die koopkrag van stedelike Swart woongebiede in die vyf grootste metropolitaanse gebiede in 1970 in die Blanke gebiede bestee is (Lucas, 1974:177-189).

In die laat sewentigerjare word sekere belangrike veranderings aan die regulasies met betrekking tot handel in stedelike Swart woongebiede aangebring. Onder meer word die beperkings op die tipe handel wat in Swart woongebiede gedryf mag word geheel en al opgehef. Swartes kon voortaan in vennootskap met Blankes, Kleurlinge of Indiërs gaan waar nie-Swart kapitaal tot 'n maksimum van $49 \%$ en Swart kapitaal tot 'n minimum van $51 \%$ beperk word. Die verslapping van handelsregulering in Swart woongebiede het die invoer van Blanke kundigheid en kapitaal moontlik gemaak en die weg vir die totstandkoming van groot supermarkte gebaan. Anderskleuriges kan egter nie die beherende belang in ondernemings in Swart woongebiede verkry nie - daar is egter meriete in hierdie reëling te vind, veral wat die korttermyn betref. 


\section{Dle fisiese struktuur van Swart woongebiede}

Die fisiese struktuur van stedelike gebiede in die Republiek van Suid-Afrika is sodanig dat die meeste Swart werkers daagliks na die Blanke stedelike gebiede en die omliggende nywerheidsgebiede pendel waar die meeste werkgeleenthede bestaan.

Wanneer daar na die tipiese komponente van 'n universele stedelike gebied soos 'n stadskern, werkgeleenthede in handelsof administratiewe aktiwiteite, woongebiede en inkoop- en gemeenskapsfasiliteite gekyk word, is dit duidelik dat Swart woongebiede nie oor die nodige funksies in ontwikkelde vorm beskik nie.

\section{Fisiese komponente van Swart woongebiede}

(i) Die stadskern wat die hart van die stedelike gebied is, is in die meeste Swart woongebiede relatief onontwikkeld.

(ii) Werkgeleenthede in handels- en administratiewe aktiwiteite wat in die stadskern gevind word, is in Swart woongebiede baie beperk.

(iii) Swart woongebiede beskik nie oor alle funksies in ontwikkelde vorm nie.

(iv) Persele vir inkoop- en gemeenskapsfasiliteite is in die meeste Swart woongebiede slegs gedeeltelik ontwikkel.

Met die uitsondering van sekere nuwe en groot Swart woongebiede, beskik die meeste Swart woongebiede feitlik oor geen ontwikkelde stedelike sisteem nie. Dit beteken dat daar weinig sprake van 'n ordelike groepering en plasing van die verskillende funksies vanaf die setel van die plaaslike bestuurstelsel tot by die individuele wooneenheid is (Botha, 1982:1).

As gevolg van die polities-historiese ontwikkeling in SuidAfrika is die voorsiening van handelsfasiliteite in Swart woongebiede onvoldoende in vergelyking met die koopkras van die plaaslike Swart bevolking. Hierdie omstandighede is van die aanleidende oorsake tot die bestaan van die informele sektor in Swart woongebiede.

\section{Beplanningstandaarde vir handelsfunksies}

Ten einde die sake-infrastruktuur in bestaande Swart woongebiede meer in lyn met die behoeftes van die inwoners te bring, word beplanningstandaarde vir handelsfunksies in Swart woongebiede kortliks omskryf.

\section{Eerste orde: 'n Sentrale sakegebied}

Dit bevat alle primêre sake- en administratiewe funksies. Die sentrale sakegebied van Blanke stede en dorpe sal in die meeste gevalle hierdie funksies vervul.

\section{Tweede orde: 'n Stadskern}

'n Tweede orde bestaan uit ' $n$ volledig-geintegreerde kompleks wat alle administratiewe, sake- en kulturele funksies bevat. Die standaard is een standskern vir elke 60000 tot 70000 inwoners.

\section{Derde orde: 'n Buurtsentrum}

Die derde orde is hoofsaaklik handelsgeoriënteerd, maar kan ook fasiliteite soos 'n kliniek of poskantoor huisves. 'n Buurtsentrum word benodig vir elke 10000 inwoners.

\section{Vierde orde: Suiwer handelsgeoriënteerd}

Dit bestaan uit die sogenaamde hoekkafee en geriefswinkel wat alleen of in groepies van twee of drie verspreid deur die woongebied voorkom. Die standaard is een winkel vir elke 1500 tot 2000 inwoners.

\section{Swart sakeondememings in Swart woongeblede in die Republiek van Suid-Afrika}

Die totale bevolking (bewoners van woonhuise en hostelle) en die aantal en soorte sakeondernemings in elke administrasieraad se gebied word in Tabel 1 aangegee.

Die meeste van hierdie Swart sakeondernemings in Swart woongebiede kom verspreid deur die woongebiede voor. Slegs in enkele nuwe Swart woongebiede is die handelfunksie as 'n eenheid beplan en ontwikkel. Met die uitsondering van sekere nuwe en groter Swart woongebiede, wil dit voorkom asof die verspreiding of struktuur van baie bestaande Swart sakeondernemings in Swart woongebiede van ' $n$ vierde orde is. In die meeste Swart woongebiede wat 'n buurtsentrum regverdig, is die ondernemings te verspreid deur die woongebiede gevestig en in baie gevalle ontbreek ' $n$ verskeidenheid van ondernemings om in die behoeftes van inwoners te voorsien. In die geval van 'n Swart woongebied wat 'n stadskern regverdig, ontbreek heelwat fasiliteite wat teenwoordig behoort te wees.

In baie Swart woongebiede is die hiërargie van sakekerns swak ontwikkel. 'n Sentrale sakegebied, stadskern en buurtsentrum bestaan nie in die ware sin van die woord in die meeste Swart woongebiede wat die spesifieke orde sakefunksie regverdig nie. Volgens die beplanningstandaarde vir handelsfunksies in Swart woongebiede blyk dit dat daar te veel tradisionele algemene handelaars, as vierde orde-ondernemings, in die oorgrote meerderheid Swart woongebiede is.

As huurmotors buite rekening gelaat word, blyk dit dat algemene handelaars minstens $40 \%$ van alle sakeondernemings in Swart woongebiede verteenwoordig, terwyl al die algemene handelaars in Suid-Afrika slegs $14,8 \%$ van die groot- en kleinhandelsensus van 1977 was. Dit is duidelik dat daar in die algemeen te veel klein tradisionele algemene handelaars is, terwyl sekere ander ondernemings ontbreek. Met die uitsondering van enkele redelike groot supermarkte, ontbreek hierdie ondernemings in baie Swart woongebiede: In die algemeen blyk dit dat, afgesien van ondernemings wat geriefsgoedere verkoop, baie van die duursame goedere-ondernemings in die meeste Swart woongebiede ontbreek. Hierdie leemte skep vir entrepreneurs besondere geleenthede wat benut behoort te word.

Om onder meer vir die tekort aan inkoopgeriewe en die vroeëre beperkende maatreëls te kompenseer, vind heelwat ongeregistreerde bedrywighede in Swart woongebiede plaas waarna kortliks verwys word.

\section{Die informele sakesektor as belangrike onderdeel van} die kleinsakesektor in Swart woongebiede.

Die informele sektor bestaan uit ondernemings en individue wat beperkte toegang tot erkende hulpbronne het. Hierdie aktiwiteite word meestal as die heimlike en ongeoorloofde ekonomiese bedrywighede van die laerinkomstegroepe beskou. Hierdie sektor is kreatief en voorsien goedere en dienste aan die laerinkomstegroepe vir wie daar min altematiewe voorsieningsbronne bestaan. Enkele voorbeelde van hierdie aktiwiteite wat ook deur die middel- en hoërinkomstegroepe bedryf word, is onder meer belastingontduiking, klein oortredings van lisensiëringsvoorskrifte, agterplaaswerktuigkundiges, deeltydse werk en die indiensneming van huisbediendes. Hierdie onaangetekende aktiwiteite is nie deel van die Bruto Binnelandse Produk nie, maar bestaan daarnáás. Omdat die sektor ongeregistreerd is, vind hierdie bedrywighede buite die stelsel van owerheidsregulering plaas.

Aangesien die informele sektor ongeregistreerd is, word dit as onwettig beskou, hoewel hulle dieselfde ekonomiese aktiwiteite as die formele sektor onder ander omstandighede bedryf. 
Tabel 1 Swart sakeondememings in Swart woongebiede per administrasieraad in die Republiek van Suid-Afrika



Geriefsgoedere

(a) Voedsel en voedseldienste Eethuis

Kafee

Melkery (Depot)

Restaurant

Slaghuis

Vrugte- en groente-

handelaar

(b) Semi-duursame geriefsgoedere

Apteek (toiletware)

Drankwinkel

Hardeware (boulyn)

\section{$\begin{array}{lll}2 & 42 \\ 2 & 4 & 42\end{array}$}

$\begin{array}{rrrrrrrrrrr}2 & 14 & 1 & & & 5 & 91 & 11 & 191 & 2,5 & 7 \\ 9 & 61 & 7 & 1 & 128 & 13 & 113 & 48 & 590 & 6,5 & 4 \\ 2 & 7 & 3 & 14 & 5 & 14 & 22 & 3 & 114 & 1,2 & 13 \\ 4 & 37 & 2 & 46 & 2 & 6 & 17 & & 174 & 1,9 & 8 \\ 4 & 59 & 5 & 30 & 16 & 18 & 198 & 16 & 535 & 5,9 & 5 \\ 12 & 22 & 6 & 23 & 4 & 2 & 239 & 13 & 464 & 5,1 & 6\end{array}$

Hout- en kolehandelaar

Supermark (kettingwinkel)

$\begin{array}{rrrrrr}2 & & 5 & 3 & 4 & 42 \\ 6 & 53 & 12 & 1 & 13 & 125\end{array}$

$\begin{array}{rrrrrr}6 & 53 & 12 & 1 & 13 & 125 \\ & 3 & 3 & & 10 & 28 \\ 1 & & 6 & & 5 & 48 \\ 7 & 14 & 9 & 1 & 32 & 126\end{array}$

$\begin{array}{llllll}6 & 7 & 2 & 2 & 7 & 119\end{array}$

$119 \quad 12$

22

$\begin{array}{rrrrrr}53 & 71 & 62 & 21 & 271 & 270 \\ & 1 & 1 & & 1 \\ & 3 & 1 & & 2\end{array}$

$\begin{array}{rrrr}270 & 64 & 448 & \\ 5 & & 1 & 4 \\ 12 & & & 3 \\ 13 & & & 2 \\ 188 & 12 & 140 & 2 \\ 9 & & & 4\end{array}$

$\begin{array}{rrrrrrrr}80 & 128 & 91 & 1399 & 72 & 3030 & 33,3 & 1 \\ & & & & & 13 & 0,1 & 24 \\ & & & & & 21 & 0,2 & 23 \\ 1 & 1 & 6 & & & 23 & 0,3 & 22 \\ 22 & 26 & 1 & 137 & 45 & 648 & 7,1 & 3 \\ & & & 1 & & 14 & 0,1 & 24\end{array}$

Duursame goedere

Elektriese winkel (radio, T.V.)

Fietswinkel

Klerewinkel

Meubelwinkel (matte)

Musiekwinkel (plate en instrumente)

Skoenwinkel

Diensondernemers

Barbier (mans)

Begrafnisondernemer

Droogskoonmaker (Depot)

Fotograaf

Haarkapper (Dames)

Hotel (motel) (nagklub)

Radioherstelwerk

Bioskoop

Ondernemings wat nie an

Swirtes behoort nie

Banke

Bouverenigings

Versekeringsondernemings

Drankwinkel/Biersaal

Poskantoor

Professionek en ander dience

Dokter

Elektrisiën

Kruiedokter

Loodgieter

Oogarts (Oogkundige)

Prokureur

Rekenmeester

Motorhandel en diems

Huurmotor

Motorbegraafplaas

Motorhawe (bande en

herstelwerk)

Onderdelehandelaar

Paneelklopper

Vervoerbedryf/Busdiens

Vervaardigingsaktiwiteite

Boukontrakteur (Bouers)

Kleremaker

Skoenmaker en leerwerke

Skrynwerker

Steenmaker

Stoffeerder

Sweiswerke (Sweisers)

$\begin{array}{lll}3 & 3 & 2 \\ 2 & 1 & 3\end{array}$

$\begin{array}{lll}8 & 0,1 & 24\end{array}$

$\begin{array}{lll}6 & 0,1 & 24\end{array}$

$\begin{array}{lll}15 & 0,2 & 23\end{array}$

$\begin{array}{llll}2 & 3 & 1 & 1\end{array}$

$\begin{array}{lll}15 & 0,2 & 23\end{array}$

Ander

Toten

Bevolking (totaal)

Behuiding: Woonhuise

4
4
5
0
6
3
3

$\begin{array}{rr} & 4 \\ 8 & \\ 8 & \\ 16 & 1 \\ 5 & \\ 1 & 1 \\ 2 & 2 \\ 1 & 3 \\ 10 & \end{array}$



$$
41
$$
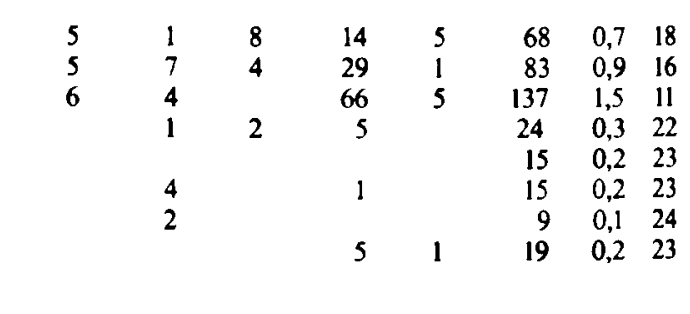

$\begin{array}{rrr}17 & 0,2 & 23 \\ 9 & 0,1 & 24 \\ 15 & 0,2 & 23 \\ 54 & 1,7 & 9 \\ 14 & 0,1 & 24 \\ 26 & 0,3 & 22 \\ 75 & 0,8 & 17 \\ 12 & 0,1 & 24 \\ 42 & 0,5 & 20 \\ 15 & 0,2 & 23 \\ 3 & & 25 \\ 10 & 0,1 & 24 \\ 7 & 0,1 & 24\end{array}$

$\begin{array}{rrrrr}386 & & 1532 & 16,8 & 2 \\ 3 & 3 & 23 & 0,3 & 22\end{array}$

$\begin{array}{rrrrrrrrrr}9 & 4 & 6 & 6 & 1 & 40 & 3 & 95 & 1,0 & 15 \\ & 3 & & 2 & 1 & 18 & & 35 & 0,4 & 21 \\ 8 & 3 & & 2 & & & & 28 & 0,3 & 22 \\ 8 & & & 21 & 1 & 40 & & 124 & 1,4 & 12\end{array}$

$\begin{array}{rrrrrrrrrr}13 & 1 & 19 & 21 & 8 & 3 & 2 & 28 & 0,3 & 22 \\ & 1 & 8 & & 21 & 1 & 40 & 124 & 1,4 & 12\end{array}$

$\begin{array}{rrr}16 & 3 & 12 \\ 3 & & 13 \\ 2 & & 4 \\ 3 & & 11 \\ & 1 & 7 \\ 3 & & 4 \\ \end{array}$


'n Onderskeid moet egter tussen die bedrywighede wat die gemeenskap benadeel en dié wat die gemeenskap tot voordeel strek, getref word. Indien die bedrywighede wat die gemeenskap bevoordeel sou registreer, sou hulle wettig wees.

Die belangrikste voordele van die informele sektor is dat dit 'n groot leemte in die verskaffing van goedere en dienste in Swart woongebiede op die regte tyd en plek vul - dit verskaf aan heelwat informele entrepreneurs ' $n$ geleentheid om ' $n$ inkomste te verdien en dus in hul eie lewensonderhoud te voorsien en selfversorgend te wees. Verder is dié sektor 'n leerskool vir die tegnieke en geskooldhede van die formele sektor en die stelsel van vrye ondernemingsgees.

Weens die uiteenlopende aard en eiesoortige karakter van die informele sektor kan die omvang daarvan nie bepaal word nie - die minimum grootte daarvan kan slegs geskat word. Volgens die aantal persone betrokke by die informele sektor in die stedelike Swart woongebiede van die Republiek van SuidAfrika, word die omvang daarvan op tussen 10 en $20 \%$ van die bevolking van die woongebiede geraam (Rive, 1983: $31-43)$.

In Suid-Afrika word die ontwikkelde en relatief onontwikkelde gedeeltes van die ekonomie deur ' $n$ verskeidenheid van wette en regulasies, ordonnansies en verordeninge gereguleer, op ' $n$ wyse wat ' $n$ beperking op die ontwikkeling van kleinskaalse ekonomiese aktiwiteite en van indiensneming meebring. Vanweë die relatief hoë vereistes wat deur wetgewing aan klein sakeondernemings gestel word, word vrye toetrede vanaf die informele sakesektor belemmer. Dit beteken dat sommige sakemanne binne die informele sektor bly. Indien toetrede tot die formele sektor makliker was, sou dit heel moontlik tot 'n verhoging van algemene sakestandaarde lei. Plaaslike owerhede behoort ordonnansies en regulasies wat die ontwikkeling van die informele sektor aan bande lê, te hersien en te vereenvoudig.

'n Vraag wat onwillekeurig na vore kom is of die informele sektor daarin belangstel om geformaliseer te word al dan nie. Volgens die vraelyste aan woongebiedbestuurders in Swart woongebiede blyk dit dat $56,5 \%$ van die respondente reken dat die ongeregistreerde sektor nie daarin belangstel om geformaliseer te word nie. In die geval van ongeregistreerde wettige bedrywighede behoort dit vir dié deel van die informele sektor moontlik gemaak te word om te kan registreer en informeel te kan voortgaan.

Daarteen behoort die ongeregistreerde wettig bedrywige persone wat daarin belangstel om geformaliseer te word, die nodige hulpverlening te ontvang om dit moontlik te maak. Daarby word ook aanvaar dat 'n werkgeleentheid baie goedkoper in die informele sektor geskep kan word. In die lig van die groot kapitaalbehoefte vir die voorsiening van formele sektor werkgeleenthede en die werkloosheidsyfer in Suid-Afrika gesien, behoort daar beslis na die werkverskaffingspotensiaal van die informele sektor gekyk te word.

\section{Koopgedrag van Swart verbrulkers}

Die koopgedrag van Swart verbruikers toon dat geriefsgoedere meestal by winkels in die Swart woongebiede gekoop word, terwyl alle ander goedere hoofsaaklik by winkels in die nabygeleë stad of dorp gekoop word. Die meeste dienste word tans nog in Blanke stede en dorpe voorsien.

Hierdie koopgedrag hou verband met faktore wat volgens die verbruiker se mening deur die kleinhandelaar beheerbaar is en sluit aspekte soos prys, verskeidenheid, kwaliteit, diens, krediet en gerief in. Die belangrikste rede vir bogenoemde koopgedrag van Swart verbruikers is die laer pryse en gerief of toeganklikheid van afsetpunte buite Swart woongebiede. Hoewel Swart sakemanne 'n goeie beeld van hierdie tekortkominge het, doen hulle skynbaar niks daaraan nie.

\section{Inkoopgeriewe in Swart woongeblede}

\section{Bestaande inkoopgeriewe}

Bestaande inkoopgeriewe in Swart woongebiede voorsien slegs gedeeltelik in die behoeftes van die meeste Swart verbruikers. Daar word grootliks in die behoefte aan onduursame of geriefsgoedere voorsien en byna glad nie in die behoefte aan duursame of uitsoek- en spesialiteitsgoedere nie.

Die houding van die meeste Swart verbruikers is nie gunstig met betrekking tot bestaande winkels in Swart woongebiede nie. Die belangrikste redes vir die toedrag van sake is hoë pryse, ou voedsel en beperkte verskeidenheid. Hoë pryse van kommoditeite is die belangrikste enkele rede vir hul onwilligheid om by winkels in die Swart woongebiede te koop. Enige betekenisvolle verlaging in pryse en ' $n$ groter verskeidenheid is alleen moontlik indien die huidige handelstruktuur in 'n hiërargiese handelstruktuur met ' $n$ buurtsentrum en stadskem vervat kan word.

\section{Die behoefte aan inkoopgeriewe in Swart woongebiede}

Volgens vraelyste aan woongebiedbestuurders in Swart woongebiede blyk dit dat daar 'n groot behoefte aan 'n verskeidenheid sakeondernemings in Swart woongebiede is, soos in Tabel 2 aangedui (Kroon, 1983).

Table 2 Die behoefte aan inkoopgeriewe in Swart woongebiede

\begin{tabular}{lrrc}
\hline Tipe onderneming & Aantal & Persentasie & $\begin{array}{c}\text { Eerste } \\
\text { prioriteit }\end{array}$ \\
\hline Kafee & 21 & 12,8 & 2 \\
Melkery & 6 & 3,7 & 6 \\
Restaurant & 11 & 6,7 & 3 \\
Slaghuis & 21 & 12,8 & 2 \\
Vrugte- en groentehandelaar & 5 & 3,0 & 7 \\
Apteek & 8 & 4,9 & 5 \\
Drankwinkel & 9 & 5,5 & 4 \\
Hardewarewinkel (boulyn) & 1 & 0,6 & 9 \\
Supermark (kettingwinkel) & 72 & 43,9 & 1 \\
Meubelwinkel & 1 & 0,6 & 9 \\
Hotel & 3 & 1,8 & 8 \\
Motorhawe & 1 & 0,6 & 9 \\
Boukontrakteur & 1 & 0,6 & 9 \\
Hout- en kolehandelaar & 1 & 0,6 & 9 \\
Banke & 3 & 1,8 & 8 \\
\hline & 164 & 100,0 & - \\
\hline
\end{tabular}

Daar bestaan ' $n$ besonder groot behoefte aan groot supermarkte wat met kettingwinkelsupermarkte in die Republiek van Suid-Afrika vergelykbaar is. Uiteraard is daar 'n verband tussen die grootte van die mark en die grootte van die onderneming. Daar bestaan verder ' $n$ groot behoefte aan onder meer slaghuise, kafees, restaurante, drankwinkels, apteke en vrugte- en groentewinkels in baie van die groter Swart woongebiede.

Hierdie behoefte aan inkoopgeriewe in Swart woongebiede skep uiteraard vir Swart entrepreneurs besondere geleenthede wat benut kan word. Volgens die vraelyste aan woongebiedbes- 
tuurders blyk dit dat die meerderheid Swart verbruikers graag die meeste van hul inkopies by winkels in die Swart woongebiede sal wil doen indien soortgelyke geriewe beskikbaar is en waar pryse, verskeidenheid en ander faktore dieselfde is. Dit blyk verder dat ' $n$ winkelsentrum wat 'n groot supermark insluit, goed deur baie Swart verbruikers op die langtermyn ondersteun sal word.

Samevattend is dit duidelik dat die bevolkingsgroei en toename in koopkrag onder meer 'n geweldige behoefte aan verskillende soorte winkels en groot supermarkte in Swan woongebiede skep. Om hierdie geleenthede te kan benut, behoor voldoende sakepersele en -geboue volgens beplanningstandaarde ontwikkel te word en die kundigheid en kapitaal op een of ander wyse aan Swartes beskikbaar gestel te word.

\section{Samevatting}

Dit is duidelik dat die huidige situasie in Suid-Afrika die resultaat van die voortdurende wisselwerking tussen sosioekonomiese en politieke kragte van hoofsaaklik die laaste eeu is. Dit het gelei tot die totstandkoming van afsonderlike woongebiede en die beperking van handel in Swart woongebiede as gevolg van onder meer die tydelikheidsbeginsel.

Met die beredenering van die permanensie, al dan nie, van Swart woongebiede het 'n groter bewuswording van die noodsaaklikheid van 'n ontwikkelde woongebied na vore getree. Dit lei onder meer in die laat sewentigerjare tot die verslapping van handelsregulering wat die weg vir groot toekomstige ontwikkeling baan.

Die fisiese struktuur van Suid-Afrika is gevolglik sodanig dat min werkgeleenthede in Swart woongebiede bestaan en dat daar weinig sprake van 'n ordelike groepering en plasing van die verskillende funksies in hierdie woongebiede is. Dit geld in besonder vir die voorsiening van handels- en diensfasiliteite, soos duidelik uit die voorgestelde beplanningstandaarde blyk. Ten einde onder meer vir die tekort aan inkoopgeriewe te kompenseer, vind heelwat informele bedrywighede - wat 'n groot leemte in die verskaffing van goedere en dienste vul in Swart woongebiede plaas. 'n Verdere uitvloeisel van die tekort aan inkoopgeriewe is dat Swartes sekere geriefsgoedere en heelwat duursame goedere buite Swart woongebiede koop.

Hierdie probleem kan deur die sistematiese beplanning van inkoopgeriewe wat groot supermarkte en ander fasiliteite insluit, oorkom word. Swartes behoort aangemoedig te word en waar nodig die nodige hulpverlening te ontvang, om hierdie geleenthede te benut.

\section{Summary}

The development of Black business enterprise in Black residential areas in the Republic of South Africa

The existing situation in South Africa is the result of the continuous interaction between socio-economic and political forces, mainly over the last century. This led to the establishment of separate Black residential areas and the restriction of commerce in Black residential areas. With the argument for permanence of Black residential areas came a greater awareness of the necessity for the development of Black residential areas. This, among other things, led to the easing of regulations concerning commerce in Black residential areas in the late seventies. The easing of regulations made the introduction of White skills and capital as well as large supermarkets possible.

The physical structure of Black residential areas

Only a few job opportunities exist in Black residential areas with the result that most of the Blacks travel to White urban areas for employment. The strong influence of White business centres as well as the political historical development in South Africa has restricted the development of commerce in Black residential areas. In most urban Black residential areas there is little provision for an orderly grouping and placing of the various economic functions. At present the commercial sector provides mainly for necessity or convenience goods. The shortcomings in the commercial sector can be identified by planning standards for a hierarchy of business centres.

Black business enterprise in Black residential areas in the Republic of South Africa

In most Black residential areas business enterprises are scattered throughout the whole residential area. Only in new Black residential areas are the commercial sectors properly planned and developed. Existing Black business enterprises consist mainly of corner shops which are grouped in twos or threes throughout the areas, thus constituting a development of the fourth order. In most areas the hierarchies of business centres are not properly developed. According to the planning standard there is, among other things, a need for large supermarkets, departmental stores, clothing, shoe, furniture and and hardware stores, filling stations, bank and building society agencies and hotels. There are very few registered service industries in Black residential areas.

The study indicates that there are 7555 Black business enterprises in Black residential areas catering for over four million people. This figure includes $\mathbf{3 0 3 0}$ general dealers, constituting over $40 \%$ of all Black businesses. General dealers constituted $14,8 \%$ of all business in South Africa in 1977. Therefore it is evident that there are too many traditional general dealers in Black residential areas. In most areas there are very few shops catering for durable goods.

The informal sector as an important part of the small business sector in Black residential areas

The economic activities in Black residential areas consist of formal and informal activities. The activities of the informal sector stem partly from the lack of sufficient business enterprise and partly from historical development. This sector plays an important role in the provision of products and services and makes people economically self-sufficient. Based on its diversified character and the number of persons engaged therein, the extent of the informal sector is estimated at between 10 to $20 \%$ of the population of the Black residential areas.

In South Africa, the developed and relatively undeveloped parts of the economy are regulated by a variety of laws, regulations and ordinances which restrict the development of smallscale economic activities and the formalizing of some informal sector activities. From this study it appears that more than half of the informal sector operators do not want to be formalized.

\section{Purchasing behaviour of Black consumers}

Blacks purchase most of their convenience products in Black residential areas, but most of their durable goods are bought at shops in White towns. The main reason for this is the high prices of products offered in the Black residential areas. Therefore it seems that there are exceptional opportunities for Black entrepreneurs in respect of the provision of durable goods and services in Black residential areas. 


\section{Purchasing facilities in Black residential areas}

It appears that shops in Black residential areas provide only partly for the needs of Black consumers. According to questionnaires completed by residential area managers there is a great need for a variety of shops in most areas. Among other things, there is a great need for large supermarkets, butcheries, cafés, restaurants, bottle stores and pharmacies in larger Black residential areas. This need creates exceptional opportunities for Black entrepreneurs. Furthermore it is evident that Black consumers would prefer to do most of their purchasing at shops in the Black residential areas, if similar facilities with regard to price, variety and other factors were available.

In conclusion it is evident that the population growth and increase in purchasing power create, among other things, a great need for large supermarkets and other facilities in Black residential areas. Blacks should be encouraged and where necessary assisted, to utilize these opportunities.

\section{Verwysings}

Botha, W.J. van H. 1982. Mangaung hernuwing. Bloemfontein: Universiteit van die Oranje-Vrystaat, bylae 4

Kroon, J. 1983. 'n Struktuuranalise van Swart sakeondernemings in die Republiek van Suid-Afrika. Potchefstroom: Proefskrif D.Com. - P.U. vir C.H.O., 327 p.

Lucas, G.H.G. 1974. Shopping Facilities for Africans in White Areas. S.-Afr. Tydskr. Ekon. vol. 42, 177-189.

Rive, L. 1983. Die rol van die informele sakesektor in die ontwikkeling van die kleinsakesektor. In Kleinsakesimposium: Referate gelewer by die Eerste Nasionale Kleinsakesimposium 9-10 Mei 1983, Johannesburg, $31-43$.

Smit, P. \& Booysen, J.J. 1981. Swart verstedeliking: Proses, patroon en strategie. Pretoria: Tafelberg, 9. 